Volume 1 Nomor 1, November 2020: h. 54 - 59

P-ISSN: 2722-4465, E-ISSN: 2746-8151

Creative Commons Attribution-NonCommercial 4.0 International

\title{
Implikasi Hukum Putusan Pengadilan terhadap Pembatalan Perkawinan
}

\author{
Muchtar Anshary Hamid Labetubun ${ }^{1 *}$, Sabri Fataruba ${ }^{2}$ \\ 1,2 Fakultas Hukum Universitas Pattimura, Ambon, Indonesia. \\ E-mail: mahlabetubun@gmail.com
}

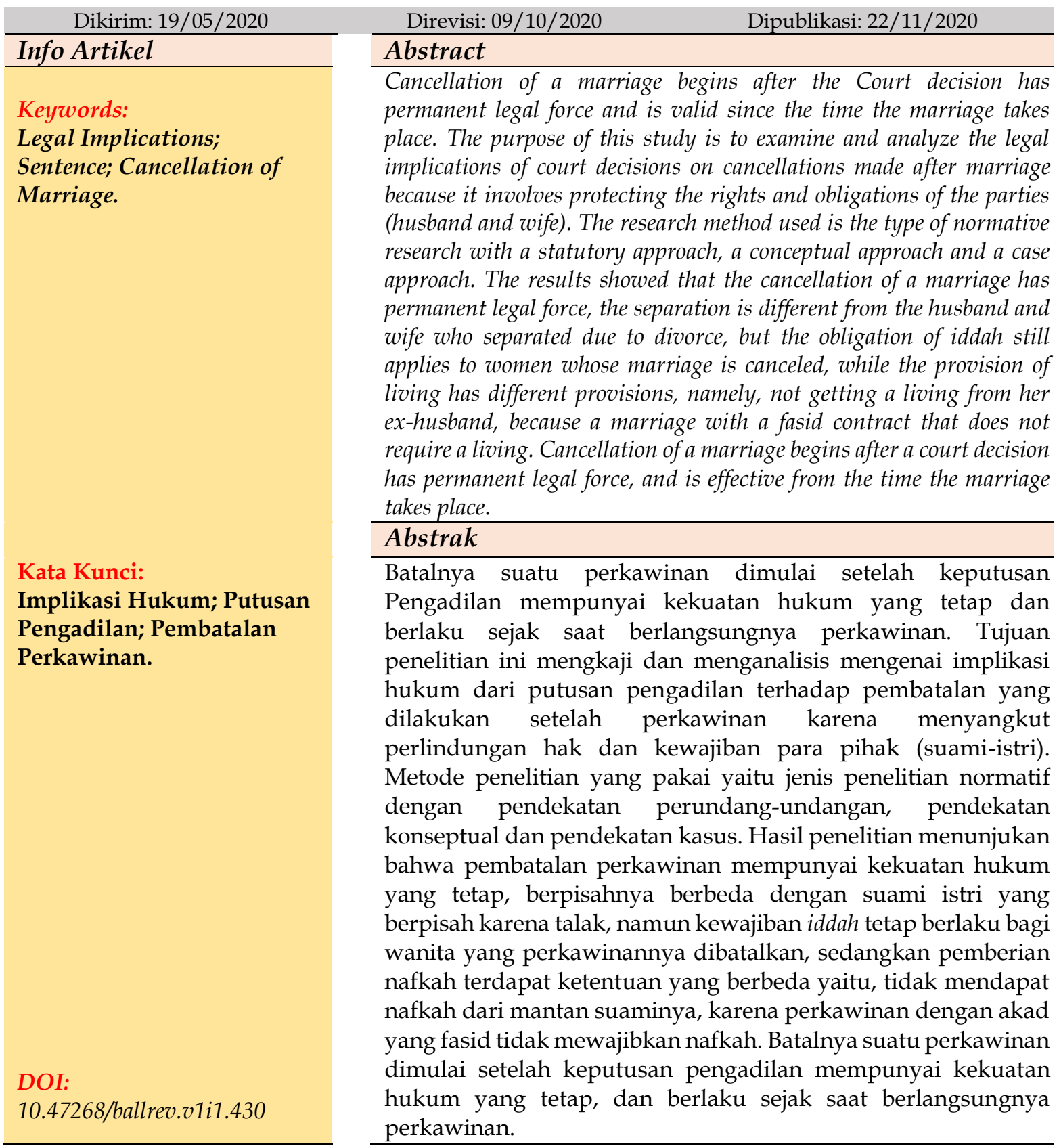




\section{Pendahuluan}

Perkawinan merupakan sebuah lembaga yang memberikan legimitasi seorang pria dan wanita untuk bisa hidup dan berkumpul bersama dalam sebuah keluarg (Latupono, 2018: 155). Selain itu, perkawinan merupakan suatu ikatan sosial atau suatu ikatan perjanjian hukum antara pribadi manusia dalam membentuk hubungan kekerabatan atau membentuk sebuah keluarga (Rizkal, 2019: 26). Perkawinan juga merupakan suatu ikatan, akad yang sangat kuat untuk mentaati perintah Allah SWT sehingga melaksanakannya merupakan ibadah (Lathif, 2020: 1), setiap perkawinan yang dilakukan ada yang berakhir sampai maut memisahkan namun ada juga yang hanya sesaat kemudian bercerai (Latupono, 2020: 242)

Manusia secara alamiah mempunyai daya tarik antara satu dengan yang lainnya untuk membina suatu hubungan. Sebagai realisasi manusia dalam membina hubungan tersebut tentunya diperlukan suatu ikatan baik secara lahir maupun batin yang disebut dengan perkawinan (Ahmad, 1999: 1). Perkawinan merupakan kebutuhan hidup seluruh umat manusia sejak zaman dahulu hingga kini, karena perkawinan merupakan masalah yang aktual untuk dibicarakan di dalam maupun di luar peraturan hukum (Prodjohamidjojo, 2007: 1). Membicarakan perkawinan selalu akan menarik karena lembaga perkawinan itulah yang melahirkan keluarga, tempat seluruh hidup dan kehidupan manusia berputar. Pergaulan hidup rumah tangga di bina dalam suasana damai, tentram, dan rasa kasih sayang antara suami istri. Suami dan Istri terdapat hak dan kewajiban yang harus dilaksanakan untuk mencapai tujuan perkawinan yaitu untuk membentuk sebuah keluarga bahagia, kekal, dan sejahtera (Zulkifli, 2019: 18). Menurut Pasal 1 Undang-undang Perkawinan, yang dimaksud dengan perkawinan ialah ikatan lahir batin antara seorang pria dengan seorang wanita sebagai suami istri dengan tujuan membentuk keluarga (rumah tangga) yang bahagia dan kekal berdasarkan Ketuhanan Yang Maha Esa.

Dari pengertian di atas maka dapat diartikan bahwa perkawinan adalah ikatan lahir batin antara pria dan wanita sebagai suami istri dengan tujuan yang sangat mulia yaitu membentuk keluarga yang kekal dan bahagia dengan didasarkan Ketuhanan Yang Maha Esa (Saleh, 2000: 14). Ikatan lahir batin itu dimaksudkan bahwa hubungan suami istri tidak boleh semata-mata hanya berupa ikatan lahiriah saja dalam makna seorang pria dan wanita hidup bersama sebagai suami istri dalam ikatan formal, tetapi juga kedua-duanya harus membina ikatan batin. Tanpa ikatan batin, ikatan lahir mudah sekali terlepas.Jalinan ikatan lahir dan ikatan batin itulah yang menjadi fondasi yang kokoh dalam membangun dan membina keluarga yang bahagia dan kekal.Keluarga/rumah tangga yang dibentuk harus didasarkan pada Ketuhanan Yang Maha Esa, ini berarti bahwa norma-norma (hukum) agama harus menjiwai perkawinan dan pembentukan keluarga yang bersangkutan.

Putusnya perkawinan karena adanya putusan pengadiln, terjadi bila para pihak tidak memenuhi syarat-syarat yang telah ditentukan untuk melangsungkan perkawinan (Hardhani et al., 2016: 1) , adapun syarat-syarat perkawinan menurut Undang-Undang Nomor 1 Tahun 1974 tentang Perkawinan (Lembaran Negara Tahun 1974 Nomor 1, Tambahan Lembaran Negara Nomor 3019) ialah sebagai berikut :

1) Adanya Persetujuan kedua calon mempelai.

2) Adanya izin kedua orangtua atau wali bagi calon mempelai yang belum berusia21 tahun.

3) Usia calon mempelai pria sudah 19 tahun dan calon mempelai wanita sudah mencapai 16 tahun, kecuali ada dispensasi dari pengadilan.

4) Antara calon mempelai pria dan calon mempelai wanita tidak dalam hubungan keluarga atau hubungan darah. 
5) Calon mempelai wanita tidak dalam ikatan perkawinan dengan pihak lain dan calon mempelai pria juga tidak dalam ikatan perkawinan dengan pihak lain, kecuali telah mendapat izin dari pengadilan untuk poligami.

6) Bagi suami istri yang telah bercerai, lalu kawin lagi, agama dan kepercayaan mereka tidak melarang kawin kembali (untuk ketiga kalinya).

7) Tidak dalam waktu tunggu bagi calon mempelai wanita yang berstatus janda.

Ketentuan pada Pasal 6 ayat 1 Undang-Undang Nomor 1 tahun 1974 yaitu “ perkawinan harus didasarkan atas persetujuan kedua calon mempelai" maka perkawinan harus disetujui oleh kedua belah pihak yang melangsungkan perkawinan tersebut, tanpa ada paksaan dari pihak manapun, karena perkawinan mempunyai maksud agar suami dan istri dapat membentuk keluarga yang kekal dan bahagia, dan sesuai pula dengan hak asasi manusia, dengan demikian pembatalan perkawinan berarti adanya putusan pengadilan yang menyatakan bahwa perkawinan yang dilaksanakan adalah tidak sah. Pasal 22 UndangUndang Nomor 1 Tahun 1974, pada prinsipnya perkawinan dapat dibatalkan, apabila para pihak tidak memenuhi syarat-syarat untuk melangsungkan perkawinan (Sudarsono, 2005: 40). Batalnya perkawinan berarti bahwa perkawinan tersebut dianggap tidak ada bahkan tidak pernah ada, dan suami isteri yang perkawinannya dibatalkan dianggap tidak pernah kawin sebagai suami isteri (Faisal, 2017: 5), dan diharamkan bagi mereka yang perkawinannya telah dibatalkan untuk melakukan hubungan suami isteri (Husaima et al., 2020: 149). Pembatalan perkawinan membawa akibat hukum baik terhadap status perkawinan yang pernah dilaksanakannya, maupun harta perkawinan. Salah satu kasus pembatalan perkawinan terjadi di Pengadilan Agama Wonosobo dan telah diputuskan melalui putusan Pengadilan Agama Wonosobo Nomor: 1175/Pdt.G/2011/PA.Wsb.

Pemohon (I binti F) memberi kuasa terhadap (Margo Lelono, SH, Tonny Fajar Oktavianto, SH dan Fitri Pratiwi, SH) selaku kuasa hukum untuk mengajukan permohonan pembatalan perkawinan ke Pengadilan Agama Wonosobo untuk membatalkan perkawinan Pemohon (I binti F) dengan Termohon (K binti W). Mengenai duduk perkaranya adalah bahwa Pemohon dengan Termohon telah melangsungkan perkawinan pada tanggal 02 April 2010 menurut Agama Islam dihadapan pegawai pencatat nikah sebagaimana tercantum dalam buku nikah Nomor 207/16/IV/2010 Tanggal 02 April 2010 yang dikeluarkan oleh KUA Kabupaten Wonosobo.

Setelah pernikahan tersebut Pemohon dan Termohon bertempat tinggal di rumah orangtua Termohon selama dua minggu, selama pernikahan tersebut Pemohon dengan Termohon belum hidup rukun serta belum pernah melakukan hubungan suami istri (Qobla dukhul). Pernikahan antara Pemohon dan Termohon terjadi karena dijodohkan oleh orangtua Pemohon dan dipaksa untuk segera menikah. Pemohon tidak mengenal Termohon secara baik sehingga pemohon tidak mencintai Termohon dan Pemohon mau menikah dengan Termohon karena rasa takut dan ingin mengabdi kepada orangtua Pemohon.

Atas permohonan Pemohon maka Termohon tidak keberatan atas permohonan Pembatalan Nikah antara Pemohon dengan Termohon. Pengadilan Agama Wonosobo pada akhirnya mengabulkanpermohonan Pemohon dan membatalkan perkawinan Pemohon dengan Termohon dengan penetapan Nomor: 1175/Pdt.G/2011/PA.Wsb, dengan berdasarkan pada keterangan Pemohon dan pengakuan Termohon.

Dasar hukum putusan Pengadilan Agama Wonosobo di atas berdasarkan pada pertimbangan bahwa perkawinan antara Pemohon dengan Termohon adalah tidak sah karena Pemohon merasa terpaksa menikah dengan Termohon sebab dijodohkan oleh orangtua. 


\section{Hasil dan Pembahasan}

Perkawinan merupakan salah satu momen sakral yang umumnya akan dilalui oleh setiap manusia. Sebagai makhluk sosial manusia mempunyai naluri untuk selalu ingin hidup bersama dan saling berinteraksi dengan sesamanya dan perkawinan adalah sah, apabila dilakukan menurut hukum masing-masing agamanya dan kepercayaannya.

Pencegahan yaitu perkawinan yang belum terlaksana, sedangkan pembatalan adalah perkawinan yang terjadi dengan tanpa memenuhi syarat-syarat sesuai undang-undang. Sebagaimana yang tertera dalam Undang-undang Perkawinan No. 1 Tahun 1974 tentang pembatalan perkawinan pada Pasal 22 yaitu "perkawinan dapat dibatalkan apabila para pihak tidak memenuhi syarat-syarat untuk melangsungkan perkawinan.

Oleh karena itu perlu dipahami perbedaan antara pembatalan perkawinan dan pencegahan perkawinan.Pencegahan perkawinan dilakukan sebelum pelangsungan perkawinan dilaksanakan disebabkan karena adanya syarat perkawinan belum terpenuhi.Pencegahan atau menghalang-halangi (stuiting) perkawinan merupakan usaha untuk menghindari adanya suatu perkawinan yang bertentangan dengan ketentuan undang-undang yang berlaku (Subekti, 2005: 33).

Dalam Undang-undang Nomor 1 Tahun 1974 tentang perkawinan Pasal 14 ayat (1): Yang dapat mencegah perkawinan ialah para keluarga dalam garis keturunan lurus ke atas dan ke bawah, saudara, wali nikah, wali pengampu dari salah seorang calon mempelai dan pihak-pihak yang berkepentingan. Ayat (2): Mereka yang tersebut pada ayat (1) pasal ini berhak juga mencegah berlangsungnya perkawinan, apabila salah seorang dari calon mempelai berada di bawah pengampuan, sehingga dengan perkawinan tersebut nyata-nyata mengakibatkan, kesengsaraan bagi calon mempelai, yang lainnya, yang mempunyai hubungan dengan orang-orang seperti tersebut dalam ayat (1) pasal ini dan selanjutnya, juga diatur dalam Pasal 15 dan Pasal 16 Undang-Undang Perkawinan. Pencegahan maupun pembatalan di dalam Undang-Undang Perkawinan pasal 13 menyatakan: Perkawinan dapat dicegah, apabila ada pihak yang tidak memenuhi syarat-syarat untuk melangsungkan perkawinan. Untuk mencegah perkawinan, harus diajukan kepada pengadilan di daerah hukum dimana perkawinan itu dilangsungkan. Hal ini diatur dalam Pasal 17 UndangUndang Perkawinan, yang bunyi lengkapnya: Ayat (1): Pencegahan perkawinan diajukan kepada pengadilan dalam daerah hukum dimana perkawinan akan dilangsungkan dengan memberitahukan juga kepada pegawai pencatat perkawinan. Ayat (2): Kepada calon-calon mempelai diberitahukan mengenai permohonan pencegahan perkawinan dimaksud dalam ayat (1) pasal ini oleh pegawai pencatat perkawinan.

Ketentuan selanjutnya bahwa pencegahan perkawinan dapat dicabut dengan putusan pengadilan atau dengan menarik kembali permohonan pencegahan pada pengadilan oleh yang mencegah.Begitu pula, perkawinan tidak dapat dilangsungkan apabila pencegahan belum dicabut. Bagaiman halnya dengan pencegahan, pembatalan perkawinan dapat pula dibatalkan, tetapi tidak setiap orang dapat mengajukan pembatalan perkawinan (Soimin, 1992: 17).

Terkait dengan akibat pembatalan perkawinan, kiranya perlu kita cermati permasalahan yang berkenaan dengan saat mulai berlakunya pembatalan perkawinan dimuat di dalam Pasal 28 ayat (1), sebagai berikut: "Batalnya suatu perkawinan dimulai setelah keputusan Pengadilan mempunyai kekuatan hukum yang tetap dan berlaku sejak saat berlangsungnya perkawinan".

1. Terhadap Anak 
Selanjutnya permasalahan yang berkenaan dengan akibat hukum terhadap pembatalan perkawinan di muat dalam Pasal 28 ayat (2), sebagai berikut: Keputusan tidak berlaku surut terhadap (1) Anak-anak yang dilahirkan dari perkawinan tersebut; (2) Suami istri yang bertindak dengan itikad baik, kecuali terhadap harta bersama, bila pembatalan perkawinan didasarkan atas adanya perkawinan lain yang lebih dahulu; (3) Orang-orang ketiga lainnya tidak termasuk dalam a dan $\mathrm{b}$ sepanjang mereka memperoleh hak-hak dengan itikad baik sebelum keputusan tentang pembatalan perkawinan mempunyai kekuatan hukum tetap.

Pasal 28 ayat (2) dapat dijelaskan bahwa keputusan tidak berlaku surut terhadap anakanak yang dilahirkan dari perkawinan tersebut. Anak-anak yang dilahirkan dalam perkawinan yang telah dibatalkan tidak berlaku surut, sehingga dengan demikian anakanak ini dianggap sah, meskipun salah seorang tuanya beritikad atau keduanya beritikad buruk, dalam Undang-Undang Nomor 1 Tahun 1974 lebih adil kiranya bahwa semua anak yang dilahirkan dalam perkawinan yang dibatalkan, meskipun kedua orang tuanya beritikad buruk, anak tersebut masih anak sah. Ini berdasarkan kemanusiaan dan kepentingan anak-anak yang tidak berdosa, patut mendapatkan perlindungan hukum, dan tidak seharusnya bila anak-anak yang tidak berdosa harus menanggung akibat tidak mempunyai status hukum yang jelas sebagai anak sah dari kedua orang tuanya yang perkawinannya dibatalkan. Perlindungan anak sebenarnya bukan hanya tanggungjawab orang tua dan keluarga, tetapi juga merupakan tangungjawab bersama masyarakat dan pemerintah (Tahamata, 2015: 63).

\section{Terhadap Harta Yang Diperoleh Selama Perkawinan}

Suami atau istri yang bertindak dengan beritikad baik, kecuali terhadap harta bersama, bila pembatalan perkawinan didasarkan atas adanya perkawinan lain yang lebih dahulu. Pembahasan mengenai harta yang ada pada dan sebelum perkawinan serta setelah pembatalan perkawinan merupakan masalah yang perlu mendapatkan pemahaman mendalam, karena ini salah satu hal yang menyangkut perlindungan hak dan kewajiban para pihak.

\section{Terhadap Hubungan Suami Istri}

Ketika perkawinan sudah dibatalkan dan mempunyai kekuatan hukum yang tetap, berpisahnya berbeda dengan suami istri yang berpisah karena talak, namun kewajiban iddah tetap berlaku bagi wanita yang perkawinannya dibatalkan. Sedangkan dalam masalah nafkah terdapat ketentuan yang berbeda yaitu, tidak mendapat nafkah dari mantan suaminya, karena perkawinan dengan akad yang fasid tidak mewajibkan nafkahm (Thalib, 2004: 83-84). Adapun saat dimulainya pembatalan perkawinan, beserta akibat hukum yang ditimbulkan dengan adanya pembatalan perkawinan oleh Pengadilan Agama ditentukan dalam Pasal 28 ayat (1) Undang-Undang Perkawinan Nomor 1 Tahun 1974 tentang Perkawinan, menentukan bahwa batalnya suatu perkawinan dimulai setelah keputusan pengadilan mempunyai kekuatan hukum yang tetap, dan berlaku sejak saat berlangsungnya perkawinan.

\section{Kesimpulan}

Kesimpulan dari penelitian ini yaitu bahwa implikasi hukum dari putusan pengadilan terkait dengan pembatalan perkawinan yaitu suatu batalnya perkawinan dimulai setelah keputusan pengadilan yang mempunyai kekuatan hukum tetap dan berlaku sejak saat berslangsungnya perkawinan. Keputusan tidak berlaku surut terhadap anak-anak yang dilahirkan dari perkawinan tersebut.Anak-anak yang dilahirkan dalam perkawinan yang telah dibatalkan tidak berlaku surut, sehingga dengan demikian anak-anak ini dianggap sah, 
meskipun salah seorang tuanya beritikad atau keduanya beritikad buruk. Suami atau istri yang bertindak dengan beritikad baik, kecuali terhadap harta bersama, bila pembatalan perkawinan didasarkan atas adanya perkawinan lain yang lebih dahulu. Harta yang ada pada dan sebelum perkawinan serta setelah pembatalan perkawinan perlu mendapatkan pemahaman mendalam, karena ini salah satu hal yang menyangkut perlindungan hak dan kewajiban para pihak

\section{Daftar Referensi}

\section{Jurnal}

Faisal. (2017). Pembatalan Perkawinan dan Pencegahannya. Al-Qadha: Jurnal Hukum Islam Dan Perundang-Undanganndangan, 4(1), 1-15. https:// doi.org/10.32505/qadha.v4i1.173

Hardhani, V. M., Mulyadi, \& Yunanto. (2016). Akibat Hukum Pembatalan Perkawinan karena Pemalsuan Identitas (Studi Kasus Putusan Nomor: 615/PDT.G/2014/PA.SMG). Diponegoro Law Journal, 17 5(3), https:// ejournal3.undip.ac.id/index.php/dlr/article/view/12054

Husaima, Hafidz, M., \& Khalid, H. (2020). Pembatalan Perkawinan dan Akibat Hukumnya: Studi Putusan Nomor 1384/Pdt.G/2013/PA Mks. Journal of Lex Theory (JLT), 1(1), 145161. http:// pasca-umi.ac.id/index.php/jlt/article/view/202

Lathif, N. (2020). Akibat Hukum dari Pembatalan Perkawinan Suami Istri yang Memiliki Hubungan Keluarga Sedarah. PALAR: Pakuan Law Review, 6(2), 1-22. https:// doi.org/10.33751/palar.v6i2.2125

Latupono, B. (2018). Pencatatan Perkawinan Di Indonesia Dikaitkan Dengan Good Governance. SASI, 24(2), 150-160. https://doi.org/10.47268/sasi.v24i2.129

Latupono, B. (2020). Pertanggungjawaban Hukum Ayah Terhadap Anak Setelah Terjadinya Perceraian. SASI, 26(2), 242-250. https:/ / doi.org/10.47268/sasi.v26i2.281

Rizkal. (2019). Poligami Tanpa Izin Isteri dalam Perspektif Hukum: Bentuk Kekerasan Psikis terhadap Isteri. Jurnal Yustika: Media Hukum Dan Keadilan, 22(1), 26-36. https:// doi.org/10.24123/yustika.v22i01.2017

Tahamata, L. C. O. (2015). Hak Hidup Anak dalam Kandungan Di Luar Perkawinan yang Sah dalam Pandangan Hak Asasi Manusia. SASI, 21(2), 57-65.

Zulkifli, S. (2019). Putusnya Perkawinan Akibat Suami Menikah Tanpa Izin dari Istri. Jurnal Hukum Kaidah, 18(3), 14-26.

Buku

Ahmad, A. B. A. (1999). Hukum Perkawinan Islam. Yogyakarta: UII Press.

Prodjohamidjojo, M. (2007). Hukum Perkawinan Indonesia. Jakarta: Karya Gemilang.

Saleh, K. W. (2000). Hukum Perkawinan Indonesia. Jakarta: Ghalia Indonesia.

Soimin, S. (1992). Hukum Orang dan Keluarga. Jakarta: Sinar Grafika.

Subekti, W. I. (2005). Hukum Peorangan dan Kekeluargaan Perdata Barat. Jakarta: Gitama Jaya.

Sudarsono. (2005). Hukum Perkawinan Nasional. Jakarta: Rineka Cipta.

Thalib, S. (2004). Hukum Kekeluargaan Indonesia. Jakarta: UI Press. 